\title{
Genetic Nature of the "Hanthoviresens" Mutation of 1 - 4 Yellow Line-Transforming into Green and Their Relationship with the Chlorophylls Content
}

\author{
Yahyo Bakhodirovich Tursunov, Miradham Fuzailovich Abzalov² \\ ${ }^{1}$ Andijan State University Named after Z. M. Babur, Andijan, Uzbekistan \\ ${ }^{2}$ Institute of Genetics and Experimental Plant Biology, Academy of Sciences of the Republic of Uzbekistan, Tashkent, Uzbekistan \\ Email: agsu_info@edu.uz,igebr_anruz@mail.ru
}

How to cite this paper: Tursunov, Y.B. and Abzalov, M.F. (2019) Genetic Nature of the "Hanthoviresens" Mutation of $1-4$ Yellow Line-Transforming into Green and Their Relationship with the Chlorophylls Content. American Journal of Plant Sciences, 10, 2047-2051.

https://doi.org/10.4236/ajps.2019.1011144

Received: September 26, 2019

Accepted: November 25, 2019

Published: November 28, 2019

Copyright $\odot 2019$ by author(s) and Scientific Research Publishing Inc. This work is licensed under the Creative Commons Attribution International License (CC BY 4.0).

http://creativecommons.org/licenses/by/4.0/

\begin{abstract}
It was determined that the yellow colour of Hanthoviresens mutation in L4 line of leaves is the result of genetic transforming into green and correlation of their hybrids on the L3. The yellow color in the leaves of L4 line is the result of recessive mutation relatively to anthocyanin colour in L3 line. This mutation and chlorophylls quantity in L4 line are being controlled by nuclear genes and high quantity of chlorophylls in L3 line is the result of linkage in gene group where gene Rstv is located or the result of the effect of pleiotropia on chlorophylls content. That is why chlorophylls quantity in plants with yellow colour is lower than in L3 line as these plants resulted from expression of $r_{p} r_{p} r_{s t}^{v} r_{s t}^{v}$ gene type.
\end{abstract}

\section{Keywords}

Chlorophyll, Experimental, Phenotype, Ontogenesis

\section{Introduction}

The chlorophyll content in plant leaves is an important ecological and physiological indicator in assessing their photosynthetic fertility.

As a result of studying natural and experimental chlorophyll mutations [1]-[7], the types of mutations were classified into four large groups and 16 subgroups. Virisens from the third group of the above groups turn green in violation of normal chlorophyll. Its phenotypic manifestation (xanthoviresens) in plants with yellow leaves turns into normal green leaves in ontogenesis, and such 
a mutation is noted as "havirs". As a result of studying a similar mutation in cotton [6] [8] [9], the gene that shows the "hantha" phenotype is recessive, and tenacious in the heterozygous state, but in the recessive homozygous state, it leads to death.

\section{Materials and Methods}

In the mutant line that we are analyzing, yellow leaves turn yellow during the ontogenetic period and become dark green during puberty with dark brown. This mutant form was taken from the gene pool of the Uzbek Institute for Cotton and Seed Breeding under the Ministry of Agriculture and Water Resources of the Republic of Uzbekistan (collection No. 011276) and belongs to the Viresent Nankin America selection and was isolated for several years by self-pollination of the "viresent" mutant of the "hanthoviresens" phenotype at the Institute genetics and experimental plant biology of the Academy of Sciences of the Republic of Uzbekistan is still preserved in the form of the L-4 line. According to the literature, this mutant is recessive in nature [5]. The second line, L-3, has a characteristic anthocyanin color and was isolated by self-pollination from the Rowden Mawloni collection form of the Institute of Genetics and Experimental Plant Biology of the Academy of Sciences of the Republic of Uzbekistan. Anthocyanin colors in the stem, in the vessels of leaves, the flowers are yellowish, and the boxes are green. In the form of leaves, both lines of five lobed, fruit branches are unlimited. The fiber of the L-4 line is dark brown, and the L-3 is white. Line L-3 has the rprpRvstRvst genotype, according to the literature on anthocyanin color [2]. As a result of mutual hybridization of these lines, reciprocal $F_{1}$ plants were obtained; the following is an analysis of the results obtained in studying the inheritance of plant color and the chlorophyll content of $\mathrm{F}_{1}$ and $\mathrm{F}_{2}$ plants.

The chlorophyll content was determined on an SF-16 spectrometer using $80 \%$ acetone. In this case, $633 \mathrm{~nm}$ and $645 \mathrm{~nm}$ were used for chlorophyll [7].

\section{Results}

Plants of the first generation of lines L-4 and L-3 have a phenotype of greenish plants, yellow color does not appear, and color of the fiber is intermediate i.e. light beige color. Hybrid analysis shows that hanthoviresens are a recessive mutation, the color of the fiber is inherited by an incomplete dominant state, on hybrids $\mathrm{F}_{1} \mathrm{~L}-4 \times \mathrm{L}-3$ and L-3 $\times$ L-4, according to the studied traits, they do not have reciprocal differences.

By the amount of chlorophyll, the L-4 and L-3 lines are very different (Table 1). Chlorophyll " $a$ " + " $b$ " in the L-4 line is $-0.54 \pm 0.06$, "a" $-0.36 \pm 0.04$, "b" $-0.18 \pm 0.02$, “a" + "b" in the line L-3 - $1.70 \pm 0.37$ "a" $-1.16 \pm 0.11$, "b" $-0.62 \pm$ 0.15 . Plants of the first generation at L- $4 \times \mathrm{L}-3-$ " $a$ " + " $b$ " $-1.1 .35 \pm 0.06$, “a" $-0.89 \pm 0.04$, "b" $-0.56 \pm 0.04$, domination coefficient $h=0.43,0.1,0.73,0.40$, $0.32,0.23$, respectively, and in both cases, incomplete dominance of the line with high indices was observed. 
Table 1. "Hanthoviresens"- hereditary mutation of yellowish green and its relationship to chlorophyll.

\begin{tabular}{|c|c|c|c|c|c|c|c|c|c|c|c|c|}
\hline \multirow{2}{*}{ Material } & \multirow{2}{*}{ Chlorophyll } & \multirow{2}{*}{$\mathrm{n}$} & \multicolumn{6}{|c|}{ The average value of the classes, calculated as $\mathrm{mg} / \mathrm{g}$ per wet leaf } & \multirow[t]{2}{*}{$\mathrm{X} \pm \mathrm{m}$} & \multirow{2}{*}{$\Delta$} & \multirow{2}{*}{$\mathrm{V}$} & \multirow{2}{*}{ Hp } \\
\hline & & & 0.25 & 0.75 & 1.25 & 1.75 & 2.25 & 2.75 & & & & \\
\hline \multirow[t]{3}{*}{$\mathrm{L}-4$} & “a” \pm "b" & 10 & 3 & 7 & & & & & $0.54 \pm 0.06$ & 6.53 & 11.9 & \\
\hline & “a” & 10 & 10 & & & & & & $0.36 \pm 0.04$ & 4.85 & 13.2 & \\
\hline & "b" & 10 & 10 & & & & & & $0.18 \pm 0.02$ & 2.21 & 12.3 & \\
\hline \multirow[t]{3}{*}{$F_{1}(\mathrm{~L} 3 \times \mathrm{L}-4)$} & “a” \pm "b” & 10 & & & 10 & & & & $1.37 \pm 0.04$ & 4.38 & 3.19 & 0.43 \\
\hline & "a" & 10 & & 10 & & & & & $0.80 \pm 0.02$ & 1.63 & 2.02 & 0.1 \\
\hline & "b" & 10 & & 10 & & & & & $0.56 \pm 0.04$ & 4.57 & 8.11 & 0.73 \\
\hline \multirow[t]{3}{*}{$F_{1}(\mathrm{~L} 3 \times \mathrm{L}-4)$} & "a" \pm "b" & 10 & & & 9 & 1 & & & $1.35 \pm 0.06$ & 6.06 & 4.48 & 0.40 \\
\hline & “a” & 10 & & 10 & & & & & $0.89 \pm 0.04$ & 4.22 & 4.71 & 0.32 \\
\hline & "b" & 10 & 8 & 2 & & & & & $0.45 \pm 0.04$ & 4.45 & 9.78 & 0.23 \\
\hline \multirow[t]{3}{*}{ L-3 } & “a” \pm "b" & 10 & & & & 10 & & & $1.70 \pm 0.37$ & 0.14 & 8.31 & \\
\hline & “a” & 10 & & 5 & 5 & & & & $1.16 \pm 0.11$ & 0.27 & 7.44 & \\
\hline & "b" & 10 & 7 & 3 & & & & & $0.62 \pm 0.15$ & 0.12 & 4.21 & \\
\hline \multirow{3}{*}{$F_{2}(\mathrm{~L} 3 \times \mathrm{L}-4)$} & “a” \pm "b" & 63 & 11 & 33 & 16 & 3 & & & $0.79 \pm 0.04$ & 0.33 & 42.3 & \\
\hline & "a" & 63 & 32 & 30 & 1 & & & & $0.49 \pm 0.03$ & 0.25 & 38.4 & \\
\hline & "b" & 63 & 54 & 9 & & & & & $0.32 \pm 0.04$ & 0.17 & 35.4 & \\
\hline \multirow[t]{3}{*}{$\begin{array}{l}\text { Of which: } \\
\text { anthocyanin }\end{array}$} & "a" \pm "b" & 9 & & 6 & 3 & & & & $0.92 \pm 0.06$ & 0.18 & 20.4 & \\
\hline & "a" & 9 & 4 & 5 & & & & & $0.50 \pm 0.04$ & 0.14 & 28.6 & \\
\hline & "b" & 9 & 6 & 3 & & & & & $0.42 \pm 0.03$ & 0.10 & 25.4 & \\
\hline \multirow[t]{3}{*}{ Green } & "a" \pm "b" & 33 & 1 & 16 & 15 & 1 & & & $0.99 \pm 0.02$ & 0.25 & 26.0 & \\
\hline & “a” & 33 & 9 & 23 & 1 & & & & $0.62 \pm 0.03$ & 0.19 & 31.6 & \\
\hline & "b" & 33 & 28 & 5 & & & & & $0.40 \pm 0.02$ & 0.10 & 23.5 & \\
\hline \multirow[t]{3}{*}{ Yellow } & “a” \pm "b" & 21 & 10 & 11 & & & & & $0.56 \pm 0.03$ & 0.17 & 30.7 & \\
\hline & “a” & 21 & 19 & 2 & & & & & $0.35 \pm 0.02$ & 0.11 & 32.7 & \\
\hline & "b" & 21 & 20 & 1 & & & & & $0.22 \pm 0.02$ & 0.10 & 47.4 & \\
\hline
\end{tabular}

Of the 63 studied $\mathrm{F}_{2}$ plants, the color of the plants could be divided into three phenotypic groups: -9 with anthocyanin, green -33 and yellow -21 with a ratio of $1: 2: 1 . \chi^{2}=6102, \mathrm{P}-0.20-0.05$. This indicates that the parent forms differ in allelic states of the same gene. The amount of chlorophyll in $\mathrm{F}_{2}$ plants was as follows: - "a" + "b" - X $=0.79 \pm 0.04$, “a" $-0.49 \pm 0.03$, "b" $-0.32 \pm 0.04$. Variability was found high. In phenotypic color groups of $\mathrm{F}_{2}$ plants, one can trace the peculiar patterns in inheritance by the content of chlorophyll. The highest indicator by this characteristic in the leaves of green plants is " $a$ " + " $b$ " $-X=0.99 \pm 0.02$, “a" $-\mathrm{X}=0.62 \pm 0.03$, " $\mathrm{b}$ " $-\mathrm{X}=0.40 \pm 0.02$ degree of variability is high. In second place are plants with anthocyanins (similar to the L-3 line), " $a$ " + " $b$ " $-X$ $=0.92 \pm 0.06$, “a" $-\mathrm{X}=0.50 \pm 0.04$ and " $\mathrm{b}$ " $-\mathrm{X}=-0.42 \pm 0.03$; in plants with 
yellow color, it was similar to the L-4 line, i.e. "a" + "b" $-\mathrm{X}=0.56 \pm 0.03$, "a" $\mathrm{X}=0.35 \pm 0.02$, "b" $-\mathrm{X}=0.22 \pm 0.02$, it was established that the variability index $\mathrm{V}$ is very high (Table 1). Experimental data show that in this hybrid combination, the parent forms differ significantly from each other in the total chlorophyll content.

Therefore, it was noted that the indicator of dominance in reciprocal plants $F_{1}$ is the hp intermediate level, and it is oriented towards the L-3 line. Given the phenotypic groups highlighted in $\mathrm{F}_{2}$, the higher the sign, the more green leafy plants for phenotypic groups. Since this plant group contains the heterozygous state of the xavirs mutation, these plants are homozygous for greenish-yellow plants, but are well developed in green anthocyanin. In plants with yellow color during ontogenesis, the return of leaves to the green state has the highest rate.

These arguments indicate that the genes involved in the development of chlorophyll in certain L-4 and anthocyanin-L-3 lines are located on the chromosomes of the $R_{s t}^{v}-r_{s t}^{v}$ dependence group, and they, due to recombination at $F_{1}$, observe the level of high variability in $\mathrm{F}_{2}$ in terms of content chlorophyll "a", as well as this indicator in plants with a green group, is proved by the level of high variability. The inheritance of "hnahta" chlorophyll, as a result of studying its biosynthesis [4], changes in gene expression during the photosynthetic apparatus during the synthesis of 5-aminolevullic acid in glutamic acid in chloroplast plants or in pigment-protein structures in chloroplast plants and in leaf ontogenesis, chlorophyll levels can be reduced to a certain leaf surface. According to our data, the difference in the chlorophyll content in the leaves of reciprocal $F_{1}$ plants is not associated with a mutation in the L-4 line, mainly due to changes in the nuclear gene.

\section{Conflicts of Interest}

The authors declare no conflicts of interest regarding the publication of this paper.

\section{References}

[1] Abdullayev, Kh.A. and Karimov, Kh.Kh. (2011) Indeksy fotosinteza v selektsii khlopchatnika, Dushanbe. izd., Donish, 267p.

[2] Abzalov, M.F., Tursunov, YA.B. and Zhurakulov, G.N. (2009) K genetike antotsianovoy okraski rasteniya khlopchatnika G.hirsutum L. Doklady AN RUz, 3-4, Tashkent, 101-103

[3] Kalam, Yu. and Oraf, K. (1974) Khlorofil'naya mutatsiya. Tallin, 58 p.

[4] Krasichkova, G.B., Asoyeva, L.M., Giller, Yu.Ye. and Sanginov, B.S. (1988) Soderzhaniya plastidnykh pigmentov $\mathrm{v}$ pokoleniyakh gibridov tonkovoloknistogo khlopchatnika. Dokl AN. Tazh SSR, 11, 756-759.

[5] Lemayeva, A.M. (1973) Khlopkovodstvo. 7, 41-73.

[6] Mansurov, A.N. (1991) Fiziologo-geneticheski analiz priznakov fotosinteza i produktivnosti u khlopchatnika, Diss. Kand biol. Nauk-Dushanbe, IFI BR AN RT, $156 \mathrm{p}$. 
[7] Shlyk, A.A. (1971) opredeleniye khlorofillov i karotinoidov v ekstraktakh zelonykh list'yev. V kn: Biokhimicheskiye metody v fiziologii rasteniy, izd-vo "Nauka", Moskva, 154-170.

[8] Sirojidinov, B.A., Abdullayev, A., Sherimbetov, A.G., Narimanov, A.A. and Omonov, B.A. (2018) Tolerance of New Introgressive Hybrid And backcross Forms Pathogenic Micromitisms (Verticillium dahliae Kleb and Fusarium oxysporum f.sp. vasinfectum). American Journal of Plant Sciences, 9, 1308-1320.

https://doi.org/10.4236/ajps.2018.96096

[9] Nosirov, YU.S. (1975) Fotosintez i genetika khloroplastov M. Nauka, 143 p. 